\title{
Effect of zinc (Zn) supplementation on quality and quantity of striped catfish Pangasianodon hypophthalmus sperm
}

\section{Suplementasi seng (Zn) terhadap kualitas dan kuantitas sperma ikan patin siam Pangasianodon hypophthalmus}

\section{Nunun Ainun Putri Sari Banun Kaliky ${ }^{1 *}$, Mia Setiawati ${ }^{1}$, Odang Carman ${ }^{1}$, Nur Bambang Priyo Utomo', Rahman ${ }^{1}$}

\author{
'Department of Aquaculture, Faculty of Fisheries and Marine Science, IPB University \\ Kampus IPB, Dramaga, Bogor 16680 \\ *Corresponding author: miasetia@apps.ipb.ac.id
}

(Received July 26, 2017; Accepted December 6, 2018)

\begin{abstract}
This study aimed to evaluate the effects of Zinc (Zn) supplementation on the quality and quantity of striped catfish sperm. Experimental design for this study was a complete randomized design with five treatments and five replications. Male broods fed with $\mathrm{Zn}$ supplementation for eight weeks. The $\mathrm{Zn}$ supplemented into the fish diet at different concentrations $(0,50,100,150$ and $200 \mathrm{mg} / \mathrm{kg}$ of feed). The results showed that $\mathrm{Zn}$ supplementation could improve the quality and quantity of striped catfish sperm. The treatments also showed significant effects on semen volume, sperm motility, sperm viability, and sperm concentration $(\mathrm{P}<0.05)$. Zn supplementation at a dose of $200 \mathrm{mg} / \mathrm{kg}$ feed demonstrated the best result has indicated by enhancement of quality and quantity of striped catfish sperm, increasing $51 \%$ of the volume, $11.6 \%$ of motility, $5.81 \%$ of viability, $54.1 \%$ of concentrations. The results suggested that $\mathrm{Zn}$ played an important role in improving reproductive performances of male striped catfish reproduction.
\end{abstract}

Keywords: quality of sperm, a quantity of sperm, striped catfish, supplementation zinc

\begin{abstract}
ABSTRAK
Penelitian ini bertujuan untuk mengetahui pengaruh suplementasi zinc $(\mathrm{Zn})$ terhadap kualitas dan kuantitas sperma ikan patin Pangasianodon hypophthalmus. Penelitian ini menggunakan rancangan acak lengkap dengan lima perlakuan dan lima ulangan. Induk jantan diberi pakan dengan suplementasi $\mathrm{Zn}$ selama 8 minggu. $\mathrm{Zn}$ disuplementasikan dengan dosis berbeda $(0,50,100,150$ dan $200 \mathrm{mg} / \mathrm{kg}$ pakan). Hasil penelitian menunjukkan bahwa suplementasi Zn dapat meningkatkan kualitas dan kuantitas sperma ikan patin sehingga berpengaruh signifikan terhadap volume semen, motilitas, viabilitas dan konsentrasi sperma $(\mathrm{P}<0,05)$. Suplementasi $\mathrm{Zn}$ pada dosis pakan $200 \mathrm{mg} / \mathrm{kg}$ menunjukkan hasil terbaik yang ditunjukkan oleh peningkatan kualitas dan kuantitas sperma ikan patin $51 \%$ volume; $11,6 \%$ motilitas; $5,81 \%$ viabilitas; $54,1 \%$ konsentrasi sperma. Hasil penelitian ini menunjukkan bahwa $\mathrm{Zn}$ memainkan peran penting dalam meningkatkan reproduksi ikan patin.
\end{abstract}

Kata kunci: kualitas dan kuantitas sperma, Ikan patin, suplementasi Zn 


\section{INTRODUCTION}

Striped catfish Pangasianodon hypophthalmus is one of the most rapidly developed freshwater species. According to the Ministry of Fisheries and Marine Affairs (KKP, 2013) the national production fo striped catfish in 2013 was 410,383 tons with $95.57 \%$ of growing each year. In 2014, the total production reached 418,002 tons with $1.82 \%$ of growing, but in 2015 there was a downturn in production as many $18.8 \%$ to 339,111 tons (KKP, 2016). The decline of production was possibly caused by inefficient broodstock management. A decline in total production could interfere with the aquaculture activity. Therefore, any kinds of interferences in aquaculture should be avoided in order to achieve a high-quality seed supply.

An excellent broodstock quality can be accomplished through genetic modification and sperm and eggs quality improvement by enhancing nutrition intake. Izquerdo et al. (2001) stated that nutrition intake improvement significantly boosted not only sperm and egg quality but also seed quality and quantity. Sperm quality and quantity is an essential parameter to determine the reproduction activity and it is measured through its concentration, motility, viability, morphology, metabolism activity, and the ability to fertilize an egg (Cabrita et al., 2014). Several factors that can affect the sperm performance are temperature, season, stress, hormone stimulation, and broodstock feed induk (Alavi et al., 2008).

Protein, lipid, carbohydrates, and vitamin are essential for reproduction, but without mineral, the reproduction process can be stranded. One of the micro mineral to induce reproduction performance is zinc $(\mathrm{Zn})$. Zinc is involved in 300 different biological processes, include DNA transcription, protein translation, cell proliferation, differentiation and apoptosis (Thomas, 2011). Zinc interacts with DNA, regulates gene activity, maintains biological integration, protects from oxidative damage and physiologically zinc is essential for growth, sexual development, and reproduction (Roy et al., 2013). Zinc deficiency potentially destructs DNA (Valco et al,. 2016). Several findings presented Zn as a beneficial in inducing both reproduction and growth performance and antioxidant response, i.e. Nile tilapia, (Morone chrysops $\times$ more saxatili), (Oreochromis niloticus $\times$ Oreochromis aureus), red sea bream (Pagrus major), elevate sperm quality (Megaloma amblycephala), trout (Salmo coruhensis), and rainbow trout (Oncorhynchus mykiss) (Gammanpila et al., 2007; Feng et al.,
2015; Li et al., 2015; Zhao et al., 2011; Buentello et al., 2009; Nguyen et al., 2008; Jiang et al., 2016; Kocabas et al., 2017).

Jiang et al. (2016) showed that feed enhancement using Zn $20-320 \mathrm{mg} / \mathrm{kg}$ was able to induce motility and viability of sperm in blunt snout bream Megaloma amblycephala. According to Payaran et al. (2014), $\mathrm{Zn}$ administration in dosage $10-30 \mathrm{mg} / \mathrm{kg}$ to male Mus musculus. Khairi et al. (2014) described that vitamin E 1886 $11 \mathrm{IU} / \mathrm{kg}$, selenium $1350 \mathrm{mg} / \mathrm{kg}$, and zinc 5200 $\mathrm{mg} / \mathrm{kg}$ could decrease semen production, motility, and concentration of male cow sperm during rainfall and high humidity. It indicated that $\mathrm{Zn}$ is crucial in reproduction activity.

Zinc in reproduction system acts as hormone receptor modulator which behave to stimulates androgen hormone (testosterone) in Leydig cell so that it will increase sperm quality (Yamaguchi et al., 2010; Yungsang et al., 2011; Egwurugwu et al., 2013; Payaran et al., 2014). Quality and quantity of sperm are closely related to testosterone synthesis and it depends to $\mathrm{Zn}$ adequacy in the feed (Roy et al., 2013). Zinc belongs to induce Leydig cell to produce testosterone (Syarifuddin et al., 2017). Zinc is also required in embryo development. Anggreini (2007) presented that $\mathrm{Zn}$ deficiency potentially interfered sperm formation and both secondary and primary sexual organ, deficiency of testicular function (testicular hypofunction) which resulted in testosterone hormone production in Leydig cell. It also inhibited DNA synthesis in the germ cell, apoptosis response induction, and reduce sperm motility (Yamaguchi et al., 2010). Therefore, this study was conducted to evaluate zinc supplementation effect towards the quality and quantity of male striped fish sperm.

\section{MATERIALS AND METHODS}

\section{Feed experimental formulation}

The main ingredient in making feed experimental was fish flour, soybean meal, meat bone meal, Pollard, fish oil, corn oil, vitamin premix, mineral, and binder (carboxymethyl cellulose). An inorganic $\mathrm{Zn}\left(\mathrm{ZnSO}_{4} .7 \mathrm{H}_{2} \mathrm{O}\right)$ was added in different dosage $(0,50,100,150,200$ $\mathrm{mg} / \mathrm{kg}$ feed). All of the ingredients were weighed based on its composition and stirred well. After that, the feed would be formed using pellet extruder and baked for 24 hours in $40^{\circ} \mathrm{C}$. The protein content of the feed was 38\%, lipid $7.5 \%$, crude fiber $3 \%$, ash $16.6 \%$, and moisture $10 \%$. 
Table 1. Formulation and proximate analysis of experimental feed

\begin{tabular}{|c|c|c|c|c|c|}
\hline \multirow{2}{*}{ Ingredients $(\mathrm{g})$} & \multicolumn{5}{|c|}{$\mathrm{Zn}$ supplementation dosage $(\mathrm{mg} / \mathrm{kg})$} \\
\hline & $\mathrm{A}(0)$ & $\mathrm{B}(50)$ & $\mathrm{C}(100)$ & $\mathrm{D}(150)$ & E (200) \\
\hline Fish flour & 150 & 150 & 150 & 150 & 150 \\
\hline MBM (meat bone meal) & 170 & 170 & 170 & 170 & 170 \\
\hline Soybean meal & 290 & 290 & 290 & 290 & 290 \\
\hline Pollard & 290 & 290 & 290 & 290 & 290 \\
\hline Fish oil & 15 & 15 & 15 & 15 & 15 \\
\hline Corn oil & 15 & 15 & 15 & 15 & 15 \\
\hline Premix $x^{*}$ & 50 & 50 & 50 & 50 & 50 \\
\hline $\mathrm{ZnSO}_{4} .7 \mathrm{H}_{2} \mathrm{O}$ & 0 & 0.05 & 0.1 & 0.15 & 0.2 \\
\hline Binder (CMC) & 20 & 20 & 20 & 20 & 20 \\
\hline Total & 1000 & 1000 & 1000 & 1000 & 1000 \\
\hline \multicolumn{6}{|c|}{ Experimental feed proximate } \\
\hline Protein $(\%)$ & 38.90 & 37.63 & 39.30 & 37.62 & 37.80 \\
\hline Lipid (\%) & 7.00 & 7.31 & 7.34 & 7.85 & 8.17 \\
\hline Ash (\%) & 16.61 & 15.85 & 17.17 & 16.75 & 16.75 \\
\hline Crude fiber $(\%)$ & 3.03 & 2.56 & 3.06 & 3.19 & 3.39 \\
\hline $\mathrm{Zn}(\mathrm{mg} \mathrm{Zn} / \mathrm{kg})$ & 66.60 & 151.31 & 224.33 & 256.68 & 274.72 \\
\hline BETN & 34.51 & 36.64 & 33.02 & 34.59 & 33.85 \\
\hline $\mathrm{GE}(\mathrm{kcal} / \mathrm{g})$ & 425.131 & 429.666 & 424.458 & 426.158 & 427.263 \\
\hline
\end{tabular}

Note : $\mathrm{BETN}=$ Non nitrogen free extract; $\mathrm{GE}=$ gross energy, $1 \mathrm{~g}$ protein $=5.6 \mathrm{kcal}, 1 \mathrm{~g}$ lipid $=9.41 \mathrm{~g}$ carbohydrate $/$ BETN $=4.1 \mathrm{kcal}$ (Watanabe, 1988).

\section{Broodstock rearing}

The experimental fish were two-year-old male striped catfish Pangasianodon hypophthalmus as many of 30 fish. The average initial weight was $2.5 \pm 0.28 \mathrm{~kg}$. Each treatment has 5 replications. The selected broodstocks were adapted in rearing cage net, then all of the broodstocks were spawned to empty the gonad before treatment. During the maturation process, all of the experimental broodstocks were reared in five cage nets sized in $3 \times 4 \times 3 \mathrm{~m}^{3}$ with density $5 \mathrm{ind} / \mathrm{net}$ and all of the nets were placed in a $25 \times 20 \times 1.5 \mathrm{~m}^{3}$ pond. The feeding rate was $3 \%$ and feeding frequency was twice a day (07.00 and 16.00) for 2 months.

\section{Observation of quantity and quality of sperm}

The observation of gonad development was done once in 14 days started from week 2, week 4 , week 6 , and week 8 . The observation included semen volume, sperm motility, viability, and concentration. The semen collection was conducted using stripping technique on the abdomen to urogenital that has been cleaned using $\mathrm{NaCl} 0.9 \%$ so that the semen would not be mixed with any dirt and it was stored in a $16 \mathrm{~mL}$ tube.
The semen collection was done at 08.00 in the morning. The semen was evaluated macroscopic and microscopically. The macroscopic evaluation consisted of volume $(\mathrm{mL})$, color, consistency or viscosity (viscous and dense), and $\mathrm{pH}(\mathrm{pH}$ indicator paper 6-8). Microscopic evaluation consisted of motility (\%), viability (\%), and concentration $\left(10^{-9}\right.$ spermatozoa cell $\left./ \mathrm{mL}\right)$. Semen volume was calculated using the printed scale on the tube. Sperm motility was determined from the amount of progressive sperm that moves forward while it was observed on the object glass using a microscope. Aquadest was put on the edge of the object glass, let it spread and activated the sperm. The observation using microscope used 400 times of magnification (Rahardianto et al., 2012).

Sperm viability was observed by dropping one drop of semen approximately $0.01 \mathrm{~mL}$, then eosinnigrosin was added using ratio 1:2. It was mixed well and spread preparation was made. It was air-dried and then observed using a microscope with three different sites. The active sperm would absorb the eosin, while the inactive or dead sperm cell would be transparent. The viability assessment was handled by comparing active sperm and total 
sperm observed (Maulana, 2014). The sperm concentration was observed in Neubauer chamber using semen dilution 200 times $(199 \mu \mathrm{L}$ formolsaline and $1 \mu \mathrm{L}$ semen). It was homogenized and counted the density each box using a microscope with 400 times of magnification. The observation was repeated five times and stated in unit $10^{9}$ cell $/ \mathrm{mL}$ (Gammanpila et al., 2007). The viability and concentration were calculated using software Optilab image raster version 1.3.2.

\section{RESULTS AND DISCUSSIONS}

\section{Results}

$\mathrm{Zn}$ supplementation in male striped catfish broodstocks feed influenced semen volume, motility, viability, and sperm concentration. The supplementation treatment of $200 \mathrm{mg} / \mathrm{kg}$ was considered as the best treatment according to semen volume, motility, viability, and sperm concentration. The semen volume analysis of striped catfish was directed for 8 weeks (Figure 1). The semen volume increased on week 4 on
150 and $200 \mathrm{mg} / \mathrm{kg}$ treatment, while 1,50 , and $100 \mathrm{mg} / \mathrm{kg}$ treatments increased on week 6 . On the week 6 to week 8 , semen volume in each treatment evenly increased and $200 \mathrm{mg} / \mathrm{kg}$ treatment increased 51\% compared to the control.

The sperm motility tended to raise after 4 weeks of rearing. It presented that $50-200 \mathrm{mg} / \mathrm{kg}$ supplementation treatment showed a significant difference $(\mathrm{P}<0.05)$ compared to control $(\mathrm{P}<0.05)$ in boosting sperm motility. Figure 2 described that $\mathrm{Zn}$ supplementation in dosage $200 \mathrm{mg} / \mathrm{kg}$ on week 8 significantly affected sperm motility. The highest motility percentage $(11.6 \%)$ was obtained from $200 \mathrm{mg} / \mathrm{kg}$ of $\mathrm{Zn}$ supplementation compared to control. Briefly, it could be described that the higher $\mathrm{Zn}$ got, the motility would get higher.

The sperm viability of male striped catfish broodstocks was shown below in Figure 3. A similar order was shown by the average value of sperm viability which increased along with $\mathrm{Zn}$ dosage as well. The $\mathrm{Zn}$ supplementation (50-200 $\mathrm{mg} / \mathrm{kg}$ ) on week 2 and week 8 significantly affected sperm viability compared to control.

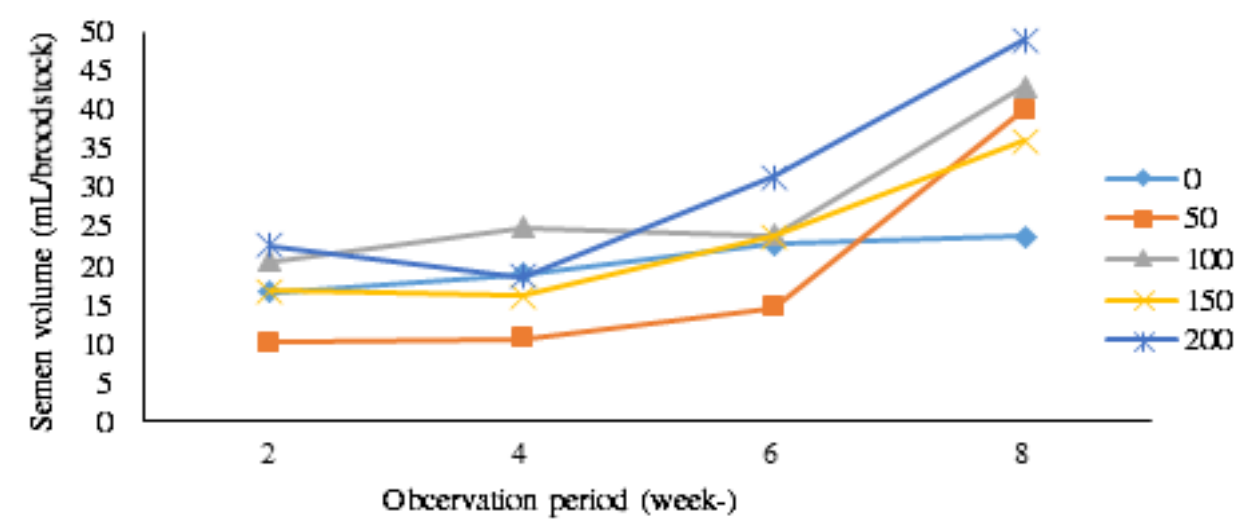

Figure 1. Striped catfish semen volume supplemented using different $\mathrm{Zn}$ dosage for 8 weeks.

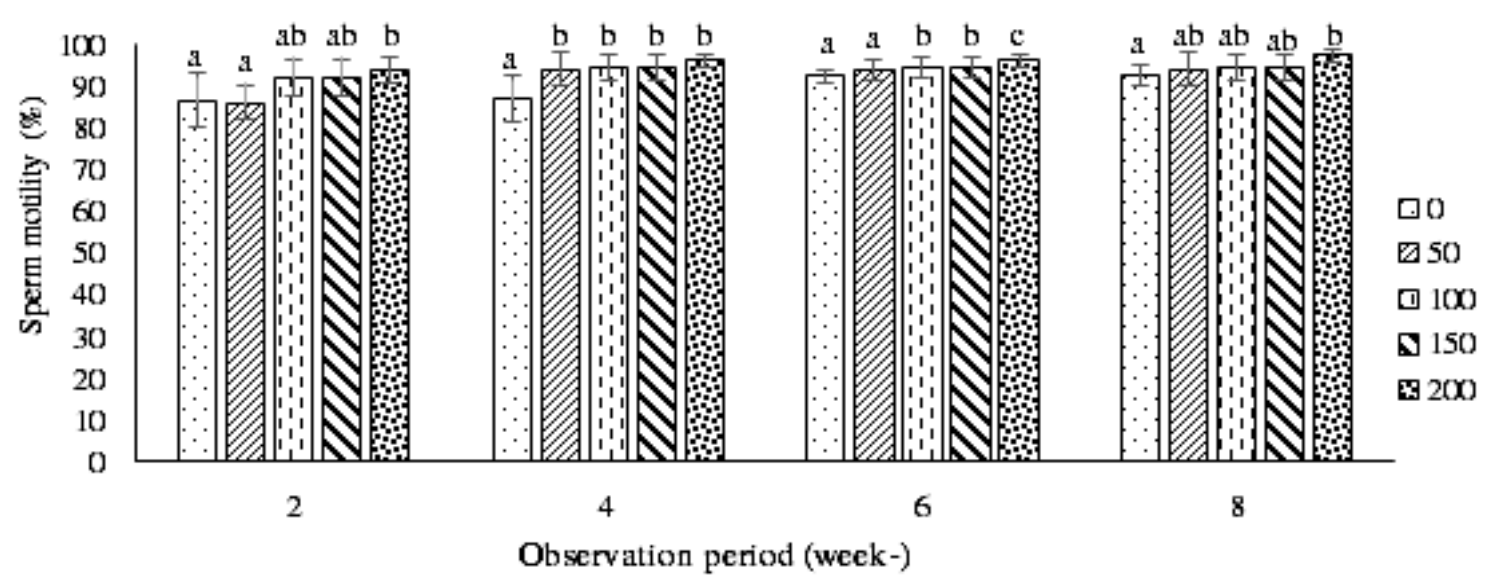

Figure 2. Sperm motility of striped catfish treated with of $\mathrm{Zn}$ feed supplementation for 8 weeks. The different letter above the bar indicates a significant difference $(\mathrm{P}<0.05)$. 


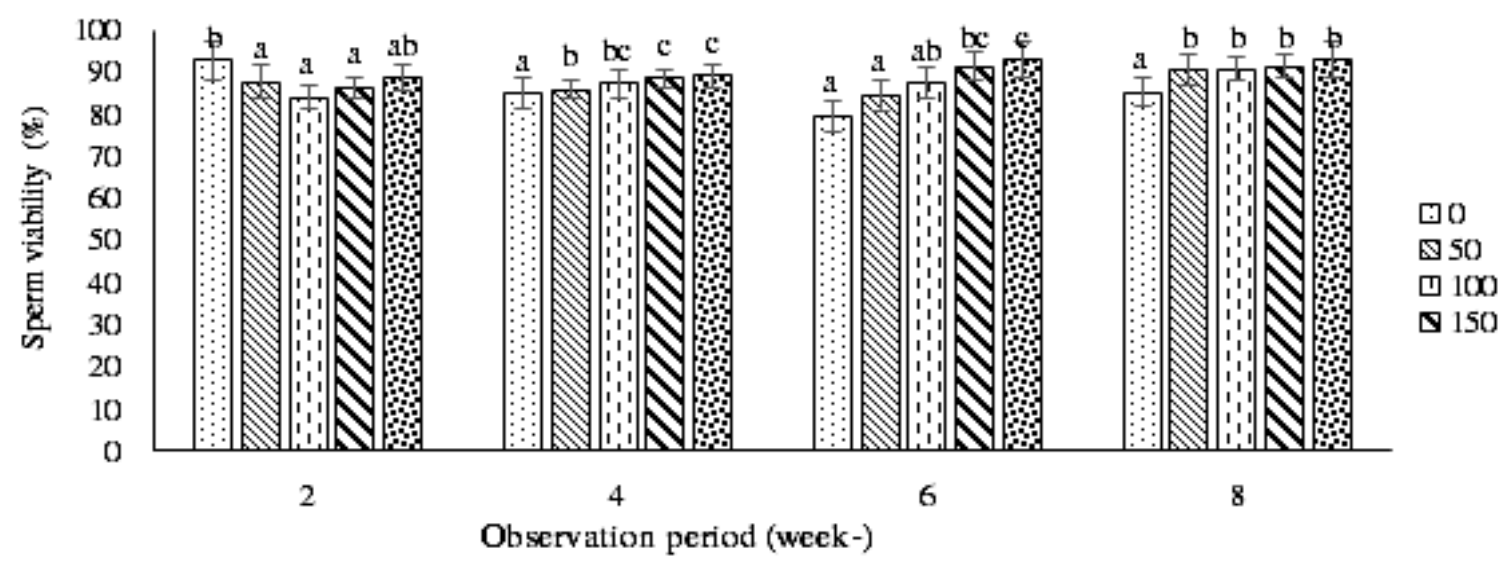

Figure 3. Sperm viability of striped catfish broodstocks treated with $\mathrm{Zn}$ feed supplementation for 8 weeks. The different letter above the bar indicates a significant difference $(\mathrm{P}<0.05)$.

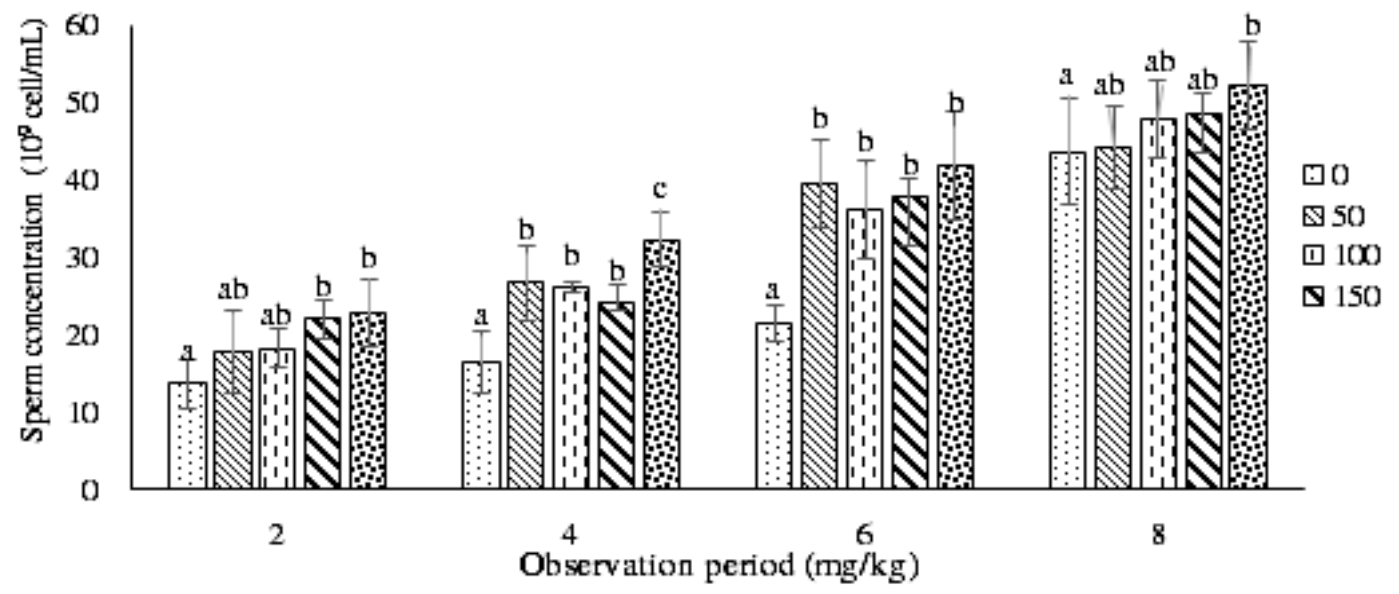

Figure 4. Sperm concentration of striped catfish broodstocks treated with $\mathrm{Zn}$ feed supplementation for 8 weeks. The different letter above the bar indicates a significant difference $(\mathrm{P}<0.05)$.

According to the result, the highest percentage (5.81\%) was obtained in $200 \mathrm{mg} / \mathrm{kg}$ treatment compared to control.

Figure 4 showed that each treatment significantly raised sperm concentration. Generally, the higher $\mathrm{Zn}$ dosage got, sperm concentration would be higher, although dosage $50-150 \mathrm{mg} / \mathrm{kg}$ was not different significantly $(P>0.05)$. The highest average value of sperm concentration was $200 \mathrm{mg} / \mathrm{kg}$ on week 8 or increased as many of $54.1 \%$ compared to control.

\section{Discussions}

$\mathrm{Zn}$ is an essential micronutrient which functioned as metalloenzyme and cofactor in the enzymatic system (NRC, 2011). Zn is involved in the various enzymatic activity in DNA synthesis and signal regulation which indirectly related to hormone regulation activity and cell cleavage (Carniola et al,. 2008). Different Zn supplementation to male striped fish broodstock influenced the semen volume, motility, viability, and sperm concentration. The semen volume increased almost in every treatment, but a different time. The dosage $50-100 \mathrm{mg} / \mathrm{kg}$ increased in week 6 , while $150-200 \mathrm{mg} / \mathrm{kg}$ rose in week 4 , and the treatment without any $\mathrm{Zn}$ supplementation showed relatively constant. The highest semen volume was obtained from $200 \mathrm{mg} / \mathrm{kg}$ treatment $(49 \mathrm{~mL})$ and it increased by $51 \%$ compared to no $\mathrm{Zn}$ supplementation treatment. This result was in line with Kumar et al. (2012) who stated that application of $\mathrm{Zn}$ supplementation as many of 150 $\mathrm{mg} / \mathrm{kg}$ feed elevated the sperm volume in a cow. In addition, $5200 \mathrm{mg} / \mathrm{kg}$ of $\mathrm{Zn}$ in livestock feed was able to avoid semen production declining in rain season with high humidity (Khairi et al., 2014).

Zinc maintains sperm survival and acts a lot in catalyzing, activating, synthesizing several important enzymes related to spermatogenesis, such as adenyl cyclase, alkaline phosphatase, and phosphatase acid (Jiang et al., 2016). Similar reports by Yamaguchi et al. (2010), Yungsang et al. (2011), Egwurugwu et al. (2013), Surhayati 
et al. (2013), Payaran et al. (2014) stated that zinc acts as a hormone receptor modulator to stimulate androgen hormone (testosterone) in Leydig cell and sperm activation and maturation. Zinc also contributes to steroidogenesis (Smith \& Akinbamijo, 2000). On the contrary, zinc deficiency decreased androgen hormone (testosterone). A low level of testosterone could possibly distract spermatozoa maturation, low testosterone secretion from Leydig cell (Khoobbakht et al., 2018).

Sperm motility, viability, and concentration are a substantial parameter to characterize the ability of sperm to fertilize the egg. Based on the result of $200 \mathrm{mg} / \mathrm{kg}$ of $\mathrm{Zn}$ supplementation resulted in $96 \%$ of motility, $93 \%$ of viability, and $37.23 \times 10^{9}$ cell $/ \mathrm{mL}$ of sperm concentration or those parameters increased $11.6 \%, 5.81 \%$, and $54.1 \%$, respectively (Figure 2, 3, 4). Jiang et al. (2016) reported that $20 \mathrm{mg} / \mathrm{kg}$ until $320 \mathrm{mg} / \mathrm{kg}$ of $\mathrm{Zn}$ supplementation in feed potentially increased sperm motility and viability on blunt snout bream Megaloma amblycephala. The related result also stated by Kocabas (2017) that $0.5-1 \mathrm{mM}$ of $\mathrm{Zn}$ was sufficient to induce sperm quality of rainbow trout Oncorhynchus mykiss. Yamaguchi et al. (2010) presented that Zn had such a crucial mineral towards rate regulation and motility duration in Japanese eel Anguilla japonica. The concentration of $\mathrm{Zn}$ mineral will rise and be accumulated in the germinal cell. Zn supplementation significantly increased semen volume, sperm motility, normal sperm percentage (Zhao et al., 2016), viability and sperm concentration (Kumar et al., 2012), activated secretion and testosterone activity, increased spermatogenic efficiency and germ cell in tubules seminiferous (Abdella et al., 2011).

Astuti et al. (2008) reported that $\mathrm{Zn}$ addition as many of $27 \mathrm{mg} / \mathrm{kg}$ could increase mouse sperm motility and concentration. Payaran et al. (2014) also reported that $\mathrm{Zn}$ dosage $10-30 \mathrm{mg} /$ $\mathrm{kg}$ was able to boost male rat sperm motility and concentration. The most significant result of this study was shown in $200 \mathrm{mg} / \mathrm{kg}$ of $\mathrm{Zn}$ supplementation. The sperm motility, viability, volume, and concentration were higher when supplemented by higher dosage of dosage. It indicated that $\mathrm{Zn}$ holds an essential role in boosting the quality and quantity of male striped catfish sperm.

The requirement of $\mathrm{Zn}$ increases, especially growth and reproduction phase (Widhyari et al., 2015). $\mathrm{Zn}$ is definitely demanded in RNA catabolism, RNA and DNA polymerase, dehydrogenase, phosphatase, reverse transcriptase, AMP aminohydrolase, ATP synthesis and carbonic acid which physically needed in sperm motility (Yamaguchi et al, 2009). Zinc is also drawn in lipid catabolism which is the energy source for sperm to actively motile. In addition, zinc is also associated with testosterone secretion, so that it's undoubtedly required in male reproduction (Chu et al., 2016). The activity of ribonuclease enzyme also demanded zinc existence to process spermatogenesis, during spermatogenesis, and at the end of spermatogenesis (Widhyari et al., 2015). Zinc also contributes to $5 \alpha$-reductase enzyme activity which functioned to transform testosterone to active biological form becomes $5 \alpha$-dihydroxy testosterone (Ali, 2007). Zinc is dependently affected reproduction hormone system which causes distractions in the spermatogenesis process (Sedigh, 2014).

\section{CONCLUSION}

Zinc supplementation in male striped catfish broodstock boosted the semen volume, sperm motility, viability, and concentration. The most significant result was presented by $200 \mathrm{mg} / \mathrm{kg}$ of zinc supplementation and elevated $51 \%$ of semen volume, $11.6 \%$ of motility, $5.81 \%$ of viability, and $54.1 \%$ of concentration compared to control.

\section{REFERENCES}

Astuti S, Muchtadi D, Astawan M, Purwantara B, Wresdiyati T. 2008. Kualitas spermatozoa tikus yang diberi tepung kedelai kaya isoflafon seng $(\mathrm{Zn})$ dan vitamin E. Media Peternakan 32: 12-21.

Alavi HMS, Cosson J, Coward K, Raffie G. 2008. Fish Spermatology. Oxford: Alpha Science International.

Ali H, Ahmed M, Baig M, Ali M. 2007. Relationship of zinc concentrations in blood and seminal plasma with various semen prameters in infertile subjects. Pakistan Journal Medical Science 23: 111-114.

Abdella AM, Elabed BH, Bakhiet AO, Gadir WSA, Adam SEI. 2011. In vivo study on lead, cadmium, zinc supplementations on spermatogenesis in albino rats. Journal of Pharmacology and Toxicology 6: 141-148.

Anggreini D. 2007. Nutrients intake, digestibility and semen quality of Garut sheep offered diets containing different dietary cation-anion. [Thesis]. Bogor: Institut Pertanian Bogor. 
Buentello AJ, Goff JB, Gatlin III DM. 2009. Dietary zinc requirement of hybrid striped bass, Morone chrysops $\times$ Morone saxatilis, and bioavailability of two chemically different zinc compounds. Journal of the World Aquaculture Society 40: 687-694.

Cabrita E, Paramo MS, Gavaia JP, Riesco FM, Valcarce DG, Sarasquerte C, Herraez MP, Robles V. 2014. Factor enhancing fish sperm quality and emerging tools for sperm analysis. Aquaculture 432: 389-401.

Carniola SR, Tassabehji MN, Hare J, Sharma G, Levenson. 2008. Zinc deficiency impairs neuronal precursor cell proliferation and induces apoptosis via p53-mediated mechanisms. Brain research 1237: 52-61.

Chu Q, Chi Z, Zhang X, Liang D, Wang X, Zhao Y, Zhang L, Zhang P. 2016. A potential role zinc transporter 7 in testosterone synthesis in mouse Leydig tumor cells. International Journal of Molecular Medicine 37: 1619-1626.

Egwurugwu CU, Ifedi CU, Uchefuna RC, Ezeokafor EN, Alagwu EA. 2013. Effects of zinc on male sex hormones and semen quality in rats. Journal Physiology Science 28: 017-022.

Feng H, Jianga M, Wena H, Wua F, Liua W. 2015. Dietary zinc requirement of adult Nile tilapia Oreochromis niloticus fed semi-purified diets, effects on tissue mineral composition and antioxidant responses. Aquaculture 439: 5359.

Gammanpila M, Yakupitiy A, Bart AN. 2007. Evaluation of the effect of dietary vitamin C, E, Zinc supplementation on reproduction performance of Nile tilapia Oreochromis niloticus. Journal Aquatic 12: 39-60.

Izquerdo H, Fernandez P, Tacon AG. 2001. Effect of broodstock nutrient on reproduction performance of fish. Aquaculture 19: 25-42

Jiang M, Wu F, Huang F, Wen H, Liu W, Tian J, Yang C, Wang W. 2016. Effect of dietary Zn on growth performance, antioxidant responses, and sperm motility of adult blunt snout bream, Megalobrama amblycephala. Aquaculture 464: 121-128.

Khairi F, Muktiani A, Ondho YS. 2014. Effect of supplementation of vitamin E, Selenium and Zinc mineral against to nutrient consumption, production and quality semen simental cow. Agriculture Peternakan 14: 6-16.

[KKP] Kementerian Kelautan dan Perikanan. 2013. Laporan tahunan direktorat produksi tahunan 2013. http://www.perikanan- budidaya.kkp.go.id. [11 April 2017].

[KKP] Kementerian Kelautan dan Perikanan. 2016. Laporan tahunan direktorat produksi tahunan 2016. http://www.kkp.go.id. [27 Juli 2017].

Kumar P, Yadav B, Yadav S. 2012. Effect zinc and selenium supplementation on semen quality of barbari bucks. Journal of Animal Research 48: 366-369.

Khoobbakht Z, Mohammadi M, Mehr ARM, Mohammadghasemi F, Sohani MM. 2018. Comparative effects of zinc oxide, zinc oxide nanoparticle and zinc-methionine on hatchability and reproductive variables in male Japanese quail. Animal Reproduction Science 10: 0378-4320.

Kocabas M, Kutluyer F. 2017. In vitro effect of zinc: evaluation of the sperm quality of endangered trout Salmo coruhensis and rainbow trout Oncorhynchus mykiss and fertilizing capacity. International Journal of Aquaculture and Fishery Sciences 3: 046-050.

Li MR, Huang CH. 2015. Effect of dietary zinc level on growth, enzyme activity and body trace element of hybrid tilapia, Oreochromis niloticus x $O$. aureus, fed soya bean meal-based diets. Aquaculture Nutrition 22: 1320-1327.

Maulana F. 2014. Physiology, morphology, preservation of climbing perch sperm and the endurance to electric shock. [Thesis]. Bogor: Institut Pertanian Bogor.

NRC [National Research Concil]. 2011. Nutrient Requirements of Fish and Shrimp. National Academy Press.

Nguyen TV, Satoh S, Haga Y, Fushimi H, Kotani T. 2008. Effect of zinc and manganese supplementation in Artemia on growth and vertebral deformity in red sea bream Pagrus major larvae. Aquaculture 285: 184-192.

Payaran OK, Wantaou B, Tendean L. 2014. Pengaruh pemberian $\mathrm{Zn}$ terhadap kualitas spermatozoa pada mencit jantan Mus musculus. Journal E-Biomedic 2: 496-500.

Rahardianto A, Abdulgani N, Trisyani N. 2012. Pengaruh konsentrasi larutan madu dalam $\mathrm{NaCl}$ fisiologis terhadap viabilitas dan motilitas spermatozoa ikan patin Pangasius pangasius selama masa penyimpanan. Jurnal Sains dan Seni ITS 1: 58-63.

Roy B, Baghel RPS, Mohanty KT, Mondal G. 2013. Zinc and male reproduction in domestic animals. Indian Journal of Animal Nutrition 30: 339-350.

Smith OB, Akinbamijo OO. 2000. Micronutrient 
and reproduction in farm animals. Journal Animal Reproduction Science 60-61: 549-560.

Thomas P. Croxford, Nicholas H, McCormick, Shannon L. Kelleher. 2011. Moderate zinc deficiency red testicular Zip6 and Zip10 abundance and impairs spermatogenesis in mice. The Journal of Nutrition 141: 359-365.

Valco M, Jomova K, Rhodes JC, Kuca K, Musflek K. 2016. Redox-and non-redox-metal induced the formation of free radicals and their role in human disease. Archives of Toxicology 90: $1-37$.

Watanabe T. 1988. Fish Nutrition and Mariculture. Tokyo: JICA.

Widhyari D, Esfandiari A, Wijaya A. 2015. The study of $\mathrm{Zn}$ supplementation on sperm quality in Frisian holstein bulls. Jurnal Peternakan Indonesia 2: 72-77.

Yamaguchi S, Miura C, Kikuchib K, Celino TF, Agusa T, Tanabe S, Miura T. 2010. Zinc is an essential trace element for spermatogenesis. Proceedings of the National Academy of Science of the United States of America 106: 10859-10864.

Yungsang C, Wanxi Y.2011. Functions of essential nutrition for high-quality spermatogenesis.
Advances in Bioscience and Biotechnology 2: 182-197.

Zhao HX, Cao JM, Liu XH, Zhu X, Chen SC, Lan HB, Wang AL. 2011. Effect of supplemental dietary zinc sources on the growth and carbohydrate utilization of tilapia smith 1840, Oreochromis niloticus $\times$ Oreochromis aureus. Aquaculture Nutrition 17: 64-72.

Zhao J, Dong X, Hu X, Long Z, Wang L, Liu Q, Sun B, Wang Q, Wu Q, Li L. 2016. Zinc levels in seminal plasma and their correlation with male infertility: a systematic review and metaanalysis. Scientific Reports 6: 1-10.

Sedigh A, Modaresi M, Pirestani A. 2014. Effect of organic and mineral zinc supplementation in the diet on reproductive hormones in mice. International Journal of Animal and Veterinary Advances 6: 77-79.

Surhayati S, Hartono M. 2013. Improvement of semen quality of boer goat supplemented with a combination of vitamin $\mathrm{E}$ and zinc mineral. Jurnal Kedokteran Hewan 1978-225X: 91-93. Syarifuddin NA, Toleng AL, Rahardja DP, Ismatoyo, Yusuf M. 2017. Improving libido and sperm quality of Bali bulls by supplementation of Moringa oleifera leaves. Media Peternakan 40: 88-93. 